\title{
МОДЕЛЮВАННЯ ПРОГРАМ ІНВЕСТИЦІЙНОЇ ПІДТРИМКИ РОЗВИТКУ АГРОСФЕРИ РЕГІОНУ
}

\author{
Турленко Наталія Володимирівна \\ кандидат економічних наук, докторант \\ Одеська національна академія харчових технологій (м. Одеса, Україна) \\ ORCID: 0000-0001-6826-8546 \\ volodymyr@wiktoriya.com
}

В статті досліджуються основні складові процесу моделювання програм інвестиційної підтримки розвитку агросфери регіону. Обгрунтовано етапи формування інвестиційної стратегії розвитку агросфери регіону. Викладено аспекти методичного забезпечення інвестиційної стратегії розвитку агросфрери регіону. Запропоновано механізм розробки та реалізації інвестиційної стратегії у агросфрері Одеської області та специфічні особливості інвестиційної стратегії агросфоерu. стування.

Ключові слова: моделювання, агросфера регіону, розвиток, сільське господарство, інвестиційна стратегія, інве-

DOI: https://doi.org/10.32845/bsnau.2019.3.21

Постановка проблеми у загальному вигляді та її зв'язок із важливими науковими чи практичними завданнями. Сьогодні на соціально-економічний розвиток агросфери регіону здійснюють вплив численні несприятливі чинники зовнішнього оточуючого середовища. У такій ситуації важливою умовою й запорукою регіонального розвитку є формування й впровадження дієвих інструментів регуляторної політики держави. Однією з найбільш важливих функцій державного регулювання є розробка стратегії соціально-економічного розвитку регіону, яка є базисом підвищення конкурентних переваг території й господарства регіону, а також підвищення рівня і якості життя населення. Особливо це важливо для розвитку агросфери й сільських територій. Проте, необхідно відмітити той факт, що для реалізації будь-яких планів та стратегічних рішень необхідно мати інвестиційні можливості. Тому дослідження саме програм інвестиційної підтримки розвитку агросфери регіону вимагає окремого дослідження.

Аналіз останніх досліджень і публікацій, в яких започатковано розв'язання даної проблеми і на які спирається автор, виділення невирішених раніше частин загальної проблеми, котрим присвячується означена стаття. Дослідження аспектів теорії та практики інвестицій, інвестиційної діяльності, що мають важливе значення для визначення пріоритетних напрямів в аграрному секторі та агробізнесі, досліджували як зарубіжні вчені Колеман Д., Фуллер Б., Херстейн Р., Джоргенсон Д., Креллє В., Лернер Д., Мегінсон, так і вічизняні І. О. Бланк, В. П. Горьовий, С. О. Гуткевич, А. А. Задоя, О. В. Захарчук, М. І. Кісіль, М. Ю. Коденська, М. М. Кропивко, В.В. Лагодієнко, І. І. Лукінов, Р.П. Мудрак, Г. М. Підлісецький, П. Т. Саблук, А.М. Ужва, П. І. Юхименко, та інші. Водночас, питання формування програм інвестиційної підтримки розвитку агросфери регіону потребують подальшого вивчення та обґрунтування.

Формулювання цілей статті (постановка завдання). Метою статті $€$ дослідження підходів до моделювання програм інвестиційної підтримки розвитку агросфери регіону. У межах досягнення мети виокремлено наступні завдання: дослідити етапи формування інвестиційної стратегії розвитку агросфери регіону, розкрити аспекти методичного забезпечення інвестиційної стратегії розвитку агросфрери регіону, запропонувати механізм розробки та реалізації інвестиційної стратегії у агросфері Одеської області.
Виклад основного матеріалу дослідження 3 повним обґрунтуванням отриманих наукових результатів. Успіх розробки й втілення у життя дієвих механізмів стратегічного планування регулювання агросфери регіону багато в чому визначається відносинами між владою, агробізнесом й сільським населенням в умовах різновекторності їх економічних інтересів. Забезпечення результативності стратегії соціально-економічного розвитку агросфери регіону вимагає застосування новітніх методів прогнозування, аналізу й оцінки факторів внутрішнього й зовнішнього середовищ, розробки прогнозних сценаріїв розвитку, формування й реалізації дієвих механізмів й інструментів державно-приватного партнерства, а також моніторингу й контролю реалізації стратегії [1, 2]. Потреба у ефективному поєднанні різних інструментів державного регулювання й застосування системного підходу до розробки стратегічних планів соціально-економічного розвитку агросфери й сільських території регіону визначається необхідністю забезпечення сталого соціально-економічного росту аграрної економіки й соціальної сфери села.

Серед стратегій розвитку агросфери та сільських територій одним з важливіших елементів є інвестиційна стратегія (рис. 1). Перший етап передбачає, що здійснення вибору базової структурної та відповідної інвестиційної стратегії на основі результатів аналізу соціально-економічного стану й оцінки перспектив розвитку аграрної сфери регіону. Для здійснення типізації агросфери регіону та обрання для неї конкретної структурної та інвестиційної стратегії можна обрати різні класи й групи показників й чинників, які характеризують найбільш важливі складові розвитку агросфери й господарства регіону загалом. Другий етап розробки інвестиційної стратегії передбачає встановлення головних завдань, визначення змісту й принципів її формування. На цьому етапі необхідно:

- сформувати концепцію розвитку агроссрери регіону, яка має стати підгрунтям для визначення пріоритетних потенційних об'єктів інвестування, що дасть змогу реалізувати структурну стратегію аграрного виробництва й вирішити гострі питання сільського розвитку;

- визначити головні напрямки інвестиційної стратегії у агросфері регіону, для активізації надходження інвестиційних ресурсів у аграрну сфреру економіки регіону, пошук джерел фрінансування інвестиційних проектів. 


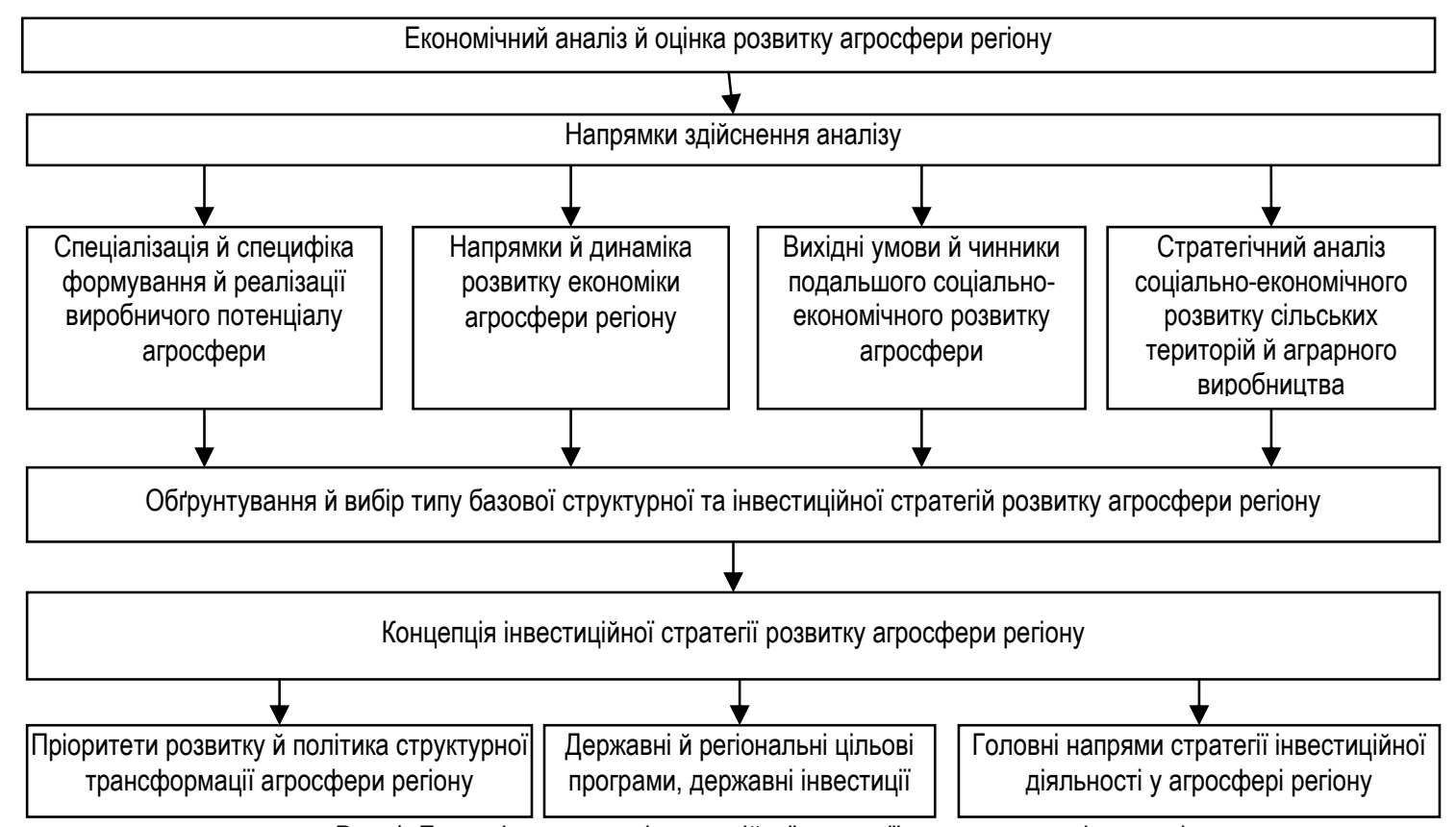

Рис. 1. Етапи формування інвестиційної стратегії розвитку агросфеери регіону

Методичне забезпечення інвестиційної стратегії розвитку агросфери регіону має включати такі структурні складові [3]:

- стратегія розвитку аграрної ссрери регіону, яка розкриває комплекс пріоритетів соціально-економічного розвитку й перспективні структурні зрушення;

- ключові напрямки стратегії інвестування у агросферу регіону, які зумовлюють успіху реалізацію структурних зрушень у агросфері. На цьому базисі формуються рішення щодо активізації інвестування у об'єкти агросфрери в регіоні, забезпечення сприятливого інвестиційного клімату, застосування інструментів залучення інвестицій, ефрективної реалізації проектів тощо.

Стан системи інвестиційного менеджменту в Одеській області та інших регіонах свідчить про існування ряду характерних проблем, зокрема відсутність чітко сформульованої та детально опрацьованої стратегії інвестування.

Механізм розробки та реалізації інвестиційної стратегії у агросфері Одеської області повинен базуватися на планомірному застосуванні методів регіонального аналізу й планування, а саме: здійснення економічного аналізу й аудиту інституційного середовища агросфери регіону; аналіз й оцінка економічного стану секторів агросфери регіону; SWOTаналіз агроссрери регіону; виявлення набору «критичних» чинників успіху, які повинні стати цільовими орієнтирами стратегії; встановлення головних цілей розвитку аграрної сфери регіону; формування й оцінка стратегічних можливостей розвитку агросфери регіону; обґрунтування вибору базового типу стратегії та її формулювання; формування набору програм, які реалізують визначені цілі розвитку агросфери регіону.

За допомогою такого аналізу здійснюється визначення ключових факторів успіху стратегічного розвитку агроссрери, орієнтованих на відродження й розвиток господарства регіону в цілому.

Різні суб'єкти аграрного підприємництва мають різні стратегії й стратегічне бачення розвитку власної інвестиційної діяльності. Отже, при стратегічному плануванні розвитку агросфери регіону та визначенні пріоритетних напрямків слід враховувати стратегії інвестування окремих суб'єктів господарювання, їх груп (кластерів).

Досвід діяльності аграрних підприємств свідчить, що формування стратегії інвестування на рівні суб'єктів господарювання стикається із певними суттєвими проблемами, зокрема: недостатністю власних джерел для фінансування інвестиційних проектів; складністю пошуку джерел залучення позикового капіталу та висока вартість кредитних ресурсів; бар'єри адміністративно-інституційного характеру тощо.

Вирішення вказаних проблем вимагає від суб'єктів агробізнесу взаємного узгодження цілей та дій із регіональним рівнем стратегічного планування, на якому має розроблятися й реалізовуватися інвестиційна стратегія у агроссрері.

Метою інвестиційної стратегії у аграрній ссрері є підвищення конкурентних позицій регіонів і підвищення рівня і якості життя сільського населення, із одночасним сприянням довгостроковому сталому соціально-економічному розвитку країни в цілому, забезпеченню її територіальної й господарської цілісності. Отже, інвестиційна стратегія має охоплювати усі сфери соціально-економічного розвитку агросфери та сільської місцевості [4].

Специфічними особливостями інвестиційної стратегії агроссрери регіону $є$ такі:

1. Ця стратегія $€$ складовою частиною регіональної стратегії соціально-економічного розвитку.

2. Стратегією визначаються найбільш важливі структурні елементи загального механізму стратегічного вибору розвитку аграрної сфери, ключовими елементами якого виступають: місія, система стратегічних цілей та завдань розвитку, набір функціональних стратегій за секторами та видами діяльності, методи й механізми консолідації та розподілу ресурсів для реалізації стратегії.

3. Стратегія визначає систему взаємозв'язків між розвитком інвестиційної діяльності регіональної агросфери та іншими ключовими складовими елементами стратегічного вибору агробізнесу, що дає змогу найбільш ефективно розробляти й реалізувати стратегії суб'єктів агробізнесу. 
Формування інвестиційної стратегії агроссрери регіону має великого значення для забезпеченні ефективного сталого розвитку села та агробізнесу. Ефективна інвестиційна стратегія агросфери регіону визначає склад й дію механізму реалізації загальних стратегічних цілей й цілей інвестування для забезпечення соціально-економічного регіону та його окремих секторів й територій. Інвестиційна стратегія дає змогу критично проаналізувати й оцінити інвестиційний потенціал агросфери регіону, забезпечити формування, розподіл, маневрування й оптимальне використання внутрішнього потенціалу інвестиційної діяльності. Виникає реальна можливість більш швидкої реалізації перспективних інвестиційних проектів.

При формуванні інвестиційної стратегії регіональної агроссрери необхідно брати до уваги всі можливі сценарії й варіанти розвитку неконтрольованих агробізнесом факторів зовнішнього оточуючого середовища й намагатися звести їх вплив на діяльність суб'єктів до мінімуму. Стратегія повинна характеризувати порівняльні переваги аграрного підприємства у здійсненні інвестиційної діяльності відносно конкуренTiB.

Стратегія інвестиційної діяльності агросфеери регіону повинна забезпечувати взаємозв'язок перспективного (довгострокового), поточного й оперативного управління інвестиційною активністю у агросфері регіону.

У ході стратегічного планування необхідно визначити набір ключових критеріальних показників вибору найбільш важливих рішень у сфері інвестиційної діяльності.

Дієва інвестиційна стратегія агросфери регіону є однією 3 важливіших базисних умов реалізації стратегічних структурних змін, як у агросфері регіону, так і у системі інституційного регулювання.

Головними принципами, які забезпечують належну підготовку, обґрунтування, прийняття й реалізацію стратегічних інвестиційних рішень у агросфрері $€$ такі: аграрна сфрера повинна розглядатися як відкрита, складна, самоорганізована соціально-економічна система; необхідно враховувати регіональні стратегії соціально-економічного розвитку та базові стратегії аграрних підприємств; слід визначити ключові сфери стратегічного розвитку інвестиційної діяльності аграрних підприємств; стратегія інвестиційної діяльності агросфери має бути гнучкою й адаптивною, надавати альтернативні варіанти стратегічного вибору; необхідне забезпечення постійного впровадження новітніх науково-технічних результатів й розробок у практику інвестиційній діяльності аграрних підприємств; слід оцінювати й враховувати інвестиційні ризики у процесі розробки й реалізації стратегічних інвестиційних рішень; доцільне залучення професійних інвестиційних менеджерів й консультантів для підвищення ефективності реалізації проектів розвитку агросфери регіону; необхідне формування структур організації й управління інвестиційною діяльністю, які відповідають завданням формування й реалізації інвестиційної стратегії агросфрери регіону.

Процес формування інвестиційної стратегії агросфери регіону передбачає такі етапи: визначення терміну розробки інвестиційної стратегії; обґрунтування вибору стратегічних цілей інвестування; визначення джерел фрінансування, напрямків й об'єктів вкладення інвестицій; розробку інвестиційних програм із чітко визначеними об'єктами, сумами та строками інвестування; здійснення оцінки якісних характеристик інвестиційної стратегії агросфери регіону; корегування стратегії у відповідь на зміни зовнішніх й внутрішніх фракторів розвитку агроссрери [5].

Насамперед, необхідно сформулювати місію інвестиційної стратегії регіональної агросфери та стратегічне бачення майбутнього її стану. Розвиток агросфери Одеської області вказує на те, що місію інвестиційної стратегії доцільно визначити як прискорення темпів розвитку й структурних трансформацій аграрної економіки регіону й підвищення рівня і якості життя мешканців сільських територій. Досягнення місії конкретизується у таких цілях інвестиційної стратегії агросфери регіону: підвищення конкурентоспроможності аграрного й переробного виробництв; підвищення рівня зайнятості та реальних доходів сільського населення.

Необхідно також зберегти структурну рівновагу між великим, середнім й малим агробізнесом.

Інвестиційна стратегія розвитку аграрної сфрери Одеської області повинна враховувати такі позиції: зміцнення територіальної, господарської й соціальної єдності регіону; нарощування інноваційного потенціалу регіональної економіки, розвиток освіти й науки; нагромадження й ефективне використання потенціалу регіону.

Формування інвестиційної стратегії доцільно здійснювати за такими рівнями: генеральна (загальна) інвестиційна стратегія агросфери регіону, у якій визначено основні стратегічні цілі й заходи, які повинні бути конкретизовані й деталізовані на рівні районних, секторальних й кластерних стратегій (рис. 2).

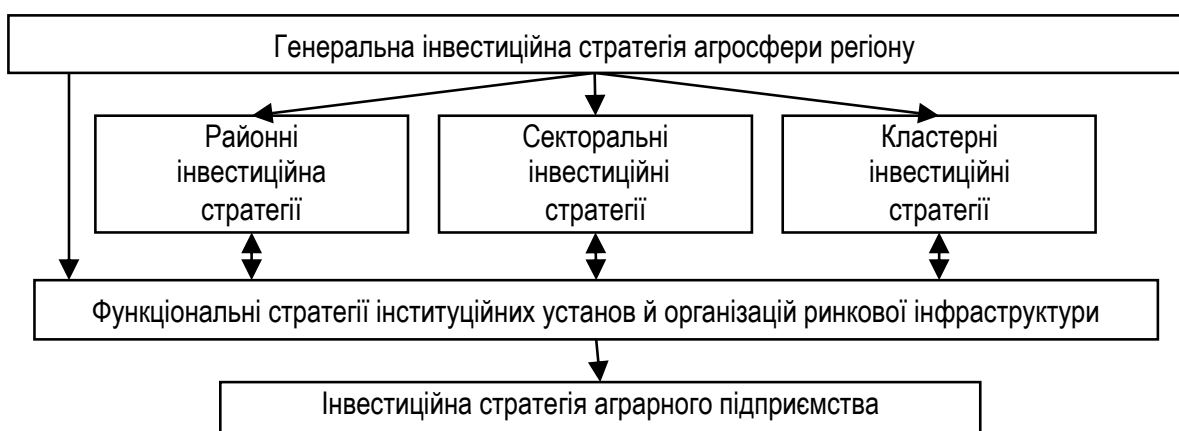

Рис. 2. Багаторівнева структура інвестиційної стратегії агроссрери регіону

Також доцільно приділити увагу стратегіями забезпечення, тобто фуннкціональним стратегіям інституційних суб'єктів ринку. Всі стратегії, включені у ієрархію, повинні доповнювати одна одну й визначити для аграрних підприємств пріоритети їх власних стратегій. 
Нижче наведені ключові завдання розвитку, заходи щодо їх досягнення, очікувані ефекти, передбачені інвестиційною стратегією агросфери Одеського регіону:

1. Маркетинг й просування агросфрери регіону на ринку інвестицій, пошук потенційних інвесторів. Це завдання передбачає: постійне рекламування й просування аграрної економіки регіону; формування єдиної інформаційної системи для поширення економічної, фінансової, інвестиційної інформації серед цільових груп споживачів; розвиток існуючих й формування нових організаційних структур для підтримки інвестиційної активності й зовнішньоекономічної діяльності аграрних підприємств регіону.

Для реалізації цього завдання необхідно забезпечити: організацію оптової торгівлі аграрною й продовольчою продукцією, як на рівні регіону, так і на міжрегіональному й міжнародному рівнях; формування консультаційних центрів й створення інформаційних ресурсів для постійного моніторингу, обробки й аналізу зовнішньої й внутрішньої інформації про стан аграрних ринків та розвиток агросфери регіону; створення міжрегіональної інформаційно-маркетингової системи й інформаційної системи інвестиційної діяльності.

Крім того, необхідна реалізація комплексної рекламної кампанії по просуванню агросфрери регіону на ринки та інформаційна підтримка міжнародного співробітництва районів й аграрних підприємств Одеської області й сусідніх країн. Для реалізації цього завдання необхідне створення та актуалізація бази даних, які цікавлять потенційних інвесторів, а саме: про сільські території регіону, виробничі можливості аграрних підприємств, стан навколишнього середовища, територіальне планування тощо.

В результаті реалізації цього завдання очікується: підвищення обсягу капіталовкладень у аграрну сфреру регіону; подолання бар'єрів у економічному співробітництві аграрних підприємств регіону із підприємствами інших регіонів й сусідніх держав; формування позитивного інвестиційного іміджу сільських територій регіону, залучення іноземних інвесторів; підвищення інвестиційної привабливості агросфрери й господарства регіону в цілому; опанування сучасними маркетинговими технологіями для реалізації маркетингової стратегії регіону.

2. Формування інноваційної системи агросфери регіону. Завдання передбачає: створення регіонального центру підтримки інновацій й трансферту технологій, який повинен забезпечити зв'язок аграрних підприємств, освітніх й наукових установ, забезпечити комерціалізацію наукових розробок, надходження інформації про новітні досягнення аграрної науки і техніки, надання організаційної підтримки інноваційним процесам; активізацію міжрегіонального та міжнародного співробітництва у сфері інноваційного інвестування та впровадження нововведень.

Для реалізації цього завдання необхідно: інформаційне забезпечення інноваційної діяльності аграрних підприємств; поширення інформації про новинки техніки та агротехнологій; інноваційний консалтинг, сприяння одержанню патентів та комерціалізації наукових розробок; просування науково-технічних досягнень на ринок інновацій.

В результаті реалізації очікується: отримання синергічного ефекту від поєднання науково-технічного й виробничого потенціалу різних підприємств, установ й організацій; підвищення техніко-технологічного рівня аграрного виробництва; підвищення рівня конкурентоспроможності аграрних підприємств Одеської області; підвищення інноваційно-інвестиційної привабливості аграрних підприємств регіону; налагодження тісного зв'язку між наукою й практикою в регіоні й країні в цілому; зростанні надходжень фінансових ресурсів у сфери науки й обсвіти.

3. Удосконалення інституційної й фінансової інфраструктури агробізнесу, розвиток діяльності існуючих та створення нових установ.

Заходами, що конкретизують це завдання є такі: формування інституційної системи фінансової підтримки агробізнесу, зокрема страхування кредитів, підтримки інновацій, інвестиційного забезпечення; сприяння кооперативному руху на селі, створення кредитних та споживчих кооперативів; підтримка міжрегіонального та міжнародного, зокрема трансграничного, співробітництва у сфері агротрейдингу; створення інформаційно-консалтингових центрів для розвитку ринкової інфрраструктури агроссрери регіону; підтримка аграрного підприємництва, сприяння регіональному й місцевому розвитку; розвиток місцевого економічного самоврядування; активізація торговельно-ярмаркової та виставкової діяльності.

В результаті реалізації очікується: підвищення обсягів надходження інвестицій у агросферу регіону; підвищення рівня конкурентоспроможності аграрних підприємств; зростання інвестиційної привабливості аграрних підприємств, сільських територій й господарства регіону в цілому; залучення стратегічних для агросфери регіону економічних, фінансових партнерів й інвесторів; нагромадження інвестиційно-фінансових ресурсів для забезпечення розвитку села та агросфери регіону; розширення господарських зв'язків 3 іншими регіонами країни та сусідніх держав.

4. Розвиток сільських територій. Змістом цього завдання $€$ розвиток існуючих і створення у сільській місцевості нових бізнес-структур у виробничій й сервісній сферах, зокрема малих форм господарювання, створення нових робочих місць.

Для реалізації цього завдання необхідно: стимулювання підприємницької ініціативи й господарської активності на селі, зокрема у сфері переробки аграрної продукції й сировини місцевого походження; підвищення доступності об'єктів виробничої й ринкової інфраструктури; формування сприятливих умов для аграрних виробників шляхом надання преференцій та допомоги, надання пільг інвесторам, маркетинг регіональних інвестиційних проектів, поширення інформації про потенціал аграрних виробників регіону.

В результаті реалізації завдання очікується: підвищення рівня зайнятості сільського населення; розвиток діяльності існуючих та створення нових аграрних підприємств; диверсифікація діяльності аграрних підприємств; розвиток малого підприємництва на селі;- зростання реальних доходів сільського населення.

5. Реструктуризація й інтеграція аграрних та переробних підприємств. Завдання передбачає: сприяння вертикальній та горизонтальній інтеграції аграрних й переробних підприємств; допомога у впровадженні у виробництво нових конкурентоспроможних видів продукції й послуг; впровадження ресурсоефективних технологій та екологічно чистих, високоякісних продуктів.

Для реалізації завдання необхідно: надання допомоги виробникам у впровадженні нових напрямків діяльності, які дозволяють підвищити їх економічну ефективність, підвищити якість та безпечність продукції; підтримка модернізації 
та технічного оновлення аграрного виробництва; сприяння впровадженню новітніх способів виробництва агропродовольчої продукції; підтримка процесів диверсифікації діяльності аграрних підприємств, розвиток зеленого туризму та ін.; підтримка кластер них ініціатив.

Очікувані результати: підвищення якості агропродовольчої продукції; охорона навколишнього середовища; оптимізація структури аграрного виробництва; підвищення доходів підприємств і зниження витрат на виробництво й реалізацію продукції.

Висновки 3 даного дослідження і перспективи подальших розвідок у даному напрямку. Важливою функцією державного регулювання є розробка стратегії соціальноекономічного розвитку регіону, яка є базисом підвищення конкурентних переваг території й господарства регіону, а також підвищення рівня і якості життя населення. Особливо це важливо для розвитку агросфери й сільських територій. Проте, необхідно відмітити той факт, що для реалізації будь-яких планів та стратегічних рішень необхідно мати інвестиційні можливості. Тому дослідження саме програм інвестиційної підт- римки розвитку агросфери регіону вимагає окремого дослідження.

Серед стратегій розвитку агросфери та сільських територій одним з важливіших елементів $є$ інвестиційна стратегія. Перший етап передбачає, що здійснення вибору базової структурної та відповідної інвестиційної стратегії на основі результатів аналізу соціально-економічного стану й оцінки перспектив розвитку аграрної сфери регіону. Другий етап розробки інвестиційної стратегії передбачає встановлення головних завдань, визначення змісту й принципів її формування.

Методичне забезпечення інвестиційної стратегії розвитку агросфери регіону має включати такі структурні складові: стратегія розвитку аграрної сфери регіону та ключові напрямки стратегії інвестування у агросферу регіону, які зумовлюють успіху.

Інвестиційна стратегія розвитку аграрної сфери Одеської області повинна враховувати такі позиції: зміцнення територіальної, господарської й соціальної єдності регіону; нарощування інноваційного потенціалу регіональної економіки, розвиток освіти й науки; нагромадження й ефективне використання потенціалу регіону.

\section{Список використаної літератури.}

1. Колібаба Р.О. Класифікація ризиків сільськогосподарського виробництва. Інструменти мінімізації ризиків. URL: http://www.minfin.gov.ua// control/uk/publish/article?art_id=57203\&cat_id=57141 (дата звернення 10.05.2019).

2. Соловйова Н.І., Шимченко Н.О. Особливості прогнозної оцінки інвестиційних ризиків в аграрному секторі. Науковий вісник Херсонського державного університету. Серія: Економічні науки. Випуск 3. 2013. С.101-104.

3. Недосекин А. О. Простейшая оценка риска инвестиционного проекта. Современные аспекты экономики. - 2002. № 11.

4. Лагодієнко В.В. Реалізація інвестиційного забезпечення інноваційної діяльності у харчовій галузі. Бізнес-Навігатор: науково-виробничий журнал Міжнародного університету бізнесу і права. Херсон. 2013. №2(31). С. 178-183.

5. Bondarenko S., Lagodienko V., Sedikova I., Kalaman O. Application of project analysis sof tware in project management in the pre-investment phase. International Journal of Mechanical Engineering and Technology, Volume 9, Issue 13, December 2018, pp. 676-684

1. Kolibaba R.O. Klasyfikatsiya ryzykiv sil's'kohospodars'koho vyrobnytstva. Instrumenty minimizatsiyi ryzykiv [Risk classification of agricultural production. Risk minimization tools]. Available at: http://www.minfin.gov.ua/ control / uk / publish / article? Art_id = 57203 \& cat_id $=57141$ (accessed 10.05.2019).

2. Solovyov N.I., Shimchenko N.O. (2013) Osoblyvosti prohnoznoyi otsinky investytsiynykh ryzykiv v ahrarnomu sektori [Features of forecasting of investment risks in the agrarian sector]. Scientific Bulletin of Kherson State University. Series: Economic Sciences. Issue 3. pp.101-104.

3. Nedosekin A.O. (2002) Prosteyshaya otsenka riska investitsionnogo proyekta. Sovremennyye aspekty ekonomiki [The simplest risk assessment of an investment project]. Modern aspects of the economy. No. 11.

4. Lagodiienko V.V. (2013) Realization of investment support of innovative activity in the food industry [Realization of investment protection of innovative activities in a restaurant] Business Navigator: a research journal of the International University of Business and Law. Kherson, 2013. №2 (31). - pp. 178-183.

5. Bondarenko S., Lagodiienko V., Sedikova I., Kalaman O. (2018) Application of project analysis sof tware in project management in the pre-investment phase. International Journal of Mechanical Engineering and Technology, Vol. 9, Issue 13, pp. 676684

Turlenko N.V., PhD, doctoral student, Odesa national academy of food technologies (Odesa, Ukraine)

Modeling investment support programs for the development of the region's agrosphere.

The article explores the main components of the process of modeling investment support programs for the development of the region's agrosphere. The stages of formation of the investment strategy of development of agrosphere of the region are substantiated. Aspects of methodological support of the investment strategy for the development of the region's agrosphere are outlined. The mechanism of development and implementation of the investment strategy in the agrosphere of Odessa region and the specific features of the investment strategy of the agrosphere are offered.

Studies have shown that an important function of state regulation is the development of a strategy for socio-economic development of the region, which is the basis for improving the competitive advantages of the territory and economy of the region, as well as improving the standard and quality of life of the population. This is especially important for the development of the agrosphere and rural areas. In order to implement any plans and strategic decisions, it is necessary to have investment opportunities, where the study 
of investment support programs for the development of the agrosphere of the region requires a separate study. It has been established that investment strategy is one of the most important elements of the agrosphere and rural development strategies. The first stage assumes that the choice of a basic structural and appropriate investment strategy based on the results of the analysis of the socioeconomic status and assessment of the prospects of development of the agricultural sector of the region. The second stage of the development of the investment strategy involves setting the main tasks, defining the content and principles of its formation.

It is substantiated that the investment strategy of development of agrarian sphere of Odessa region should take into account the following positions: strengthening of territorial, economic and social unity of the region; enhancing the innovation potential of the regional economy, developing education and science; accumulation and effective utilization of the region's potential. The process of formation of the investment strategy of the agrosphere of the region involves the following stages: determining the term of development of the investment strategy; substantiation of the choice of strategic investment goals; identification of sources of financing, directions and objects of investment; development of investment programs with clearly defined objects, amounts and terms of investment; assessment of the qualitative characteristics of the investment strategy of the agrosphere of the region; adjusting the strategy in response to changes in external and internal factors in the development of the agrosphere.

Key words: modeling, agrosphere of the region, development, agriculture, investment strategy, investment.

Дата надходження до редакції: 27.08.2019 р. 